\title{
EVALUATION OF PERFORMANCE OF ASYMMETRICALLY DUAL SYSTEM STRUCTURES USING PUSHOVER AND TIME HISTORY ANALYSES
}

\author{
by Kurdian Suprapto ${ }^{1}$ and Sudarto ${ }^{2}$
}

\begin{abstract}
Performance-based design is becoming increasingly popular in designing a seismic resistant building. In the study, a twelvestory, reinforced concrete office building with asymmetric configuration using dual system located in seismic zone 6 was designed conforming to the Indonesian Seismic Code SNI 03-1726-2002 and the Indonesian Concrete Building Code SNI 03-2847-2002. The seismic performance of the building was evaluated using the Static Nonlinear (Pushover) Analysis and Inelastic Dynamic Time History Analysis. The performance point obtained from the pushover analysis was defined using various methods, such as FEMA 356, ATC-40, FEMA 440, and SNI 03-1726-2002. The result of the study indicated that the highest performance point was that obtained according to FEMA 356 and FEMA 440, whereas the lowest value was that in accordance with SNI-03-1726-2002. The roof displacement difference of that obtained from El-Centro dynamic analysis and performance-point pushover analysis can reach up to $5 \mathrm{~cm}$ and $2.4 \mathrm{~cm}$ in $X$-and $Y$-directions, respectively. This indicates that the pushover analysis is quite accurate for evaluating the corresponding building since the first mode shape is quite dominant.
\end{abstract}

Keywords: performance-based design; pushover analysis; time history analysis.

\section{PENDAHULUAN}

Pada perkembangan terbaru disain bangunan tahan gempa mulai dikenalkan suatu konsep dari ATC $40^{1}$ dan FEMA-273 2 yaitu konsep Performance Based Seismic Design. Konsep Performance Based Seismic Design adalah konsep yang menetapkan tingkat kinerja (Performance level) yang diharapkan dapat dicapai saat struktur dilanda gempa dengan intensitas tertentu. Pada konsep ini analisa yang digunakan untuk mengevaluasi kinerjanya adalah analisa nonlinier. FEMA 356 (Prestandard and Commentary For The Seismic Rehabilitation Of Buildings), ${ }^{3}$ mengatur tingkat kinerja suatu bangunan sebagai berikut :

$>$ Operational

$>$ Immediate Occupancy (IO)

$>$ Life Safety $($ LS $)$

$>$ Collapse Prevention (CP)

Evaluasi kinerja dapat dilakukan dengan analisa pushover (beban dorong statik), sedangkan titik kinerja yang merupakan besarnya perpindahan maksimum struktur saat gempa rencana terjadi harus ditentukan tersendiri dengan berbagai metode yang terdapat di ATC$40^{1}$, FEMA $356^{3}$, FEMA $440^{4}$ dan SNI 03-1726-2002.

${ }^{1}$ Dosen Jurusan Teknik Sipil, Fakultas Teknik Sipil dan Perencanaan, Institut Teknologi Sepuluh Nopember (ITS), Kampus ITS, Keputih, Sukolilo, Surabaya 60111 Indonesia.

${ }^{2}$ Sarjana Jurusan Teknik Sipil, Fakultas Teknik Sipil dan Perencanaan, Institut Teknologi Sepuluh Nopember (ITS), Kampus ITS, Keputih, Sukolilo, Surabaya 60111 Indonesia.

Note. The manuscript for this paper was submitted for review and possible publication on May 1, 2009; approved on October 26, 2009. Discussion open until February 2010. This paper is part of the ITS Journal of Civil Engineering, Vol. 29, No.1, May 2009. (C) ITS Journal of Civil Engineering, ISSN 2086-1206/2009.

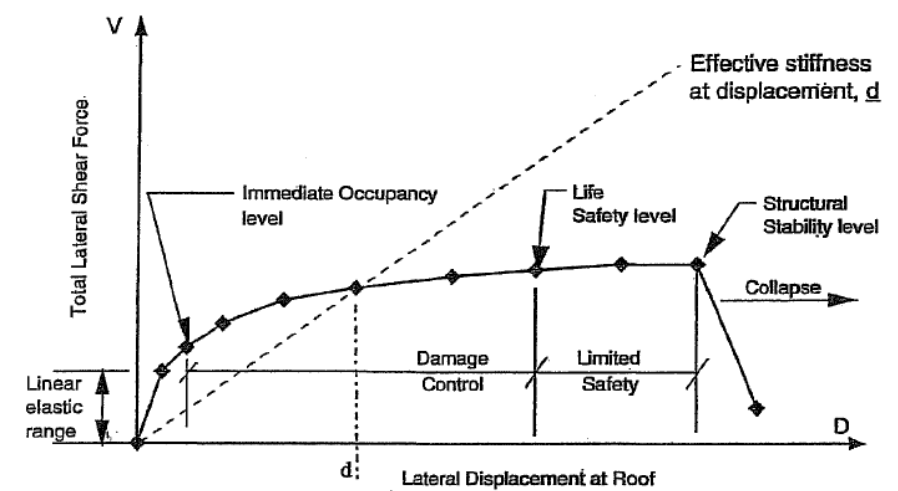

(a)

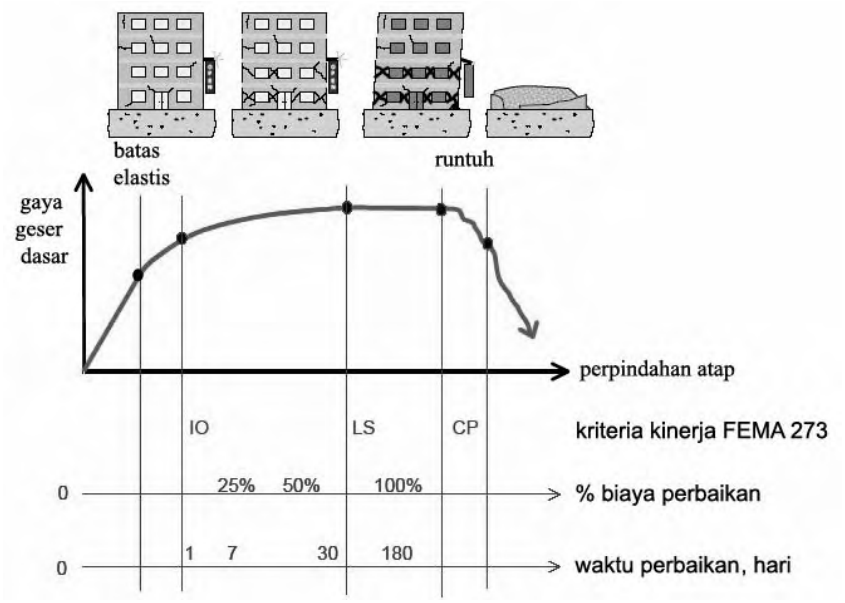

(b)

Gambar 1. (a) Kurva kapasitas ATC-40 dan (b) Kurva kapasitas FEMA 273

Karena analisa pushover mempunyai keterbatasan yaitu masih bersifat statik monotonik maka perilaku seismik suatu struktur tak simetris juga harus dilakukan dengan prosedur analisa dinamik yang salah satunya adalah analisa inelastis dinamik riwayat waktu (inelastic dynamic time history analysis) sehingga sasaran kinerja yang menjadi hal penting dari perencanaan berbasis kinerja dapat terpenuhi. 
Untuk analisa dinamik riwayat waktu mengacu SNI 03-1726-2002 ${ }^{5}$ Pasal 7.3.4 disebutkan bahwa untuk mengurangi ketidakpastian mengenai kondisi lokasi, maka paling sedikit harus ditinjau 4 buah akselerogram dari 4 gempa yang berbeda, salah satunya harus diambil akselerogram gempa El Centro N-S yang telah direkam pada tanggal 15 Mei 1940 di California. Untuk itu dalam studi ini analisa menggunakan 5 macam percepatan gempa yaitu El Centro 1940, Santa Cruz (Loma Prieta) 17 Oktober 1989, Sierra Madre (California) 28 Juni $1991,{ }^{6}$ Cape Mendocino 23 April 1992, ${ }^{7}$ dan Northridge (California) 17 Januari 1994. ${ }^{8}$ Adapun gambar akselerogram dari kelima gempa di atas dapat dilihat pada Gambar 2 hingga Gambar 6.

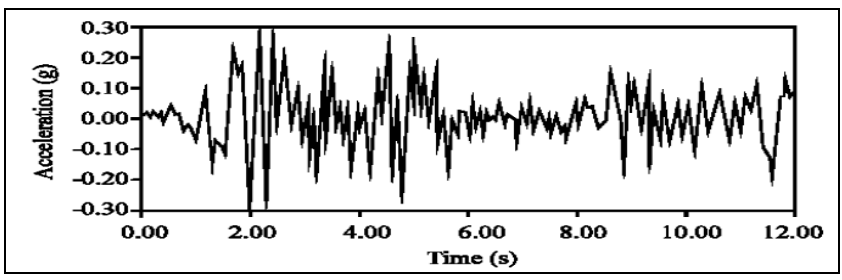

Gambar 2. Akselerogram gempa El Centro 1940

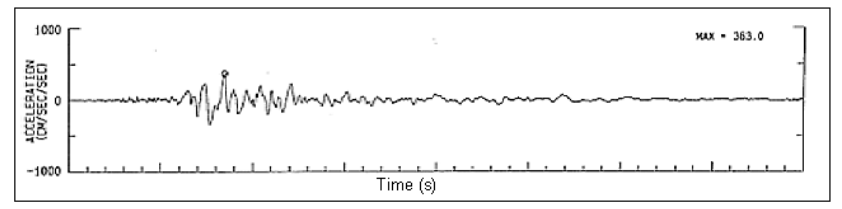

Gambar 3. Akselerogram gempa Santa Cruz (Luma Prieta) 17 Oktober 1989

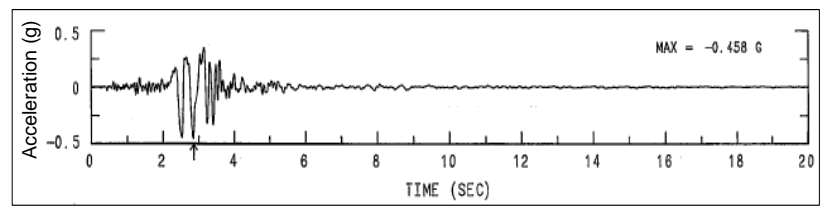

Gambar 4. Akselerogram gempa Sierra Madre (California) 28 Juni 1991

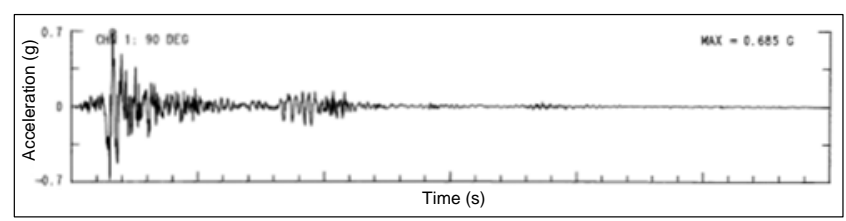

Gambar 5. Akselerogram gempa Cape Mendocino 23 April 1992

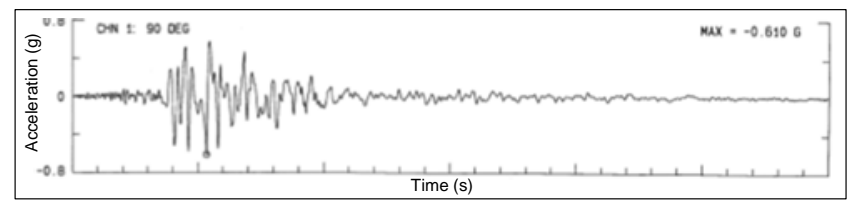

Gambar 6. Akselerogram gempa Northridge (California) 17 Januari 1994

\section{TUJUAN}

Adapun tujuan yang ingin dicapai dari penulisan ini diuraikan sebagai berikut:

1. Menilai kinerja struktur sistem ganda tak simetris dengan FEMA $356,{ }^{3}$ FEMA $440,{ }^{4}$ SNI 03-1726-2002, dan ATC- $40 .{ }^{6}$

2. Mengetahui mekanisme runtuh dari struktur sistem ganda tak simetris berdasarkan hasil analisa pushover.

3. Menilai keakuratan analisa pushover jika dibandingkan dengan analisa riwayat waktu.

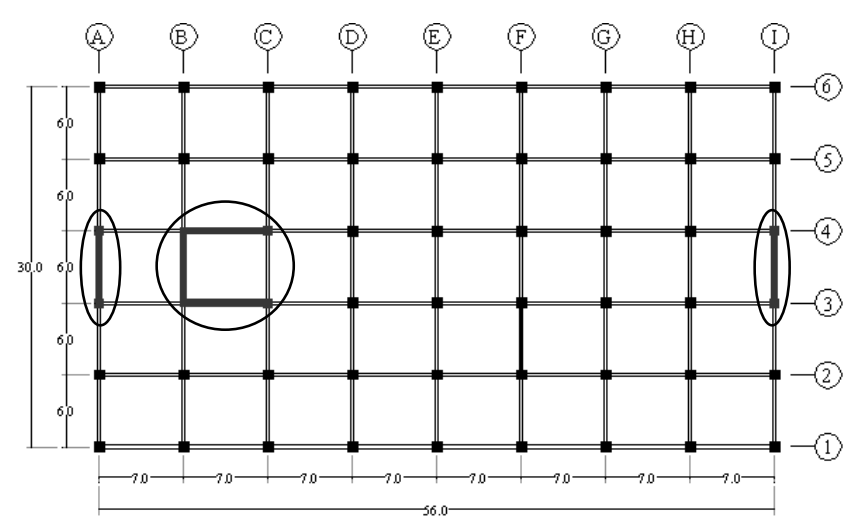

Gambar 7. Denah model

(daerah yang dilingkari merupakan dinding geser)

\section{PEMODELAN}

Data gedung untuk pemodelan dapat dilihat dibawah ini sedangkan denah tipikal gedung dapat dilihat pada Gambar 7. Pemodelan balok dan kolom memakai elemen frame, pemodelan pelat memakai membran, sedangkan pemodelan dinding geser memakai elemen shell. Setelah dilakukan pembebanan kemudian pemodelan struktur dirunning memakai program ETABS 9.0.7. Hasil dari analisa dapat dilihat pada Tabel 2 dan Tabel 3. Hasil analisa memperlihatkan bahwa akselerasi arah $\mathrm{x}$ dan arah y mempunyai ratio modal load participation lebih besar dari $90 \%$ dan partisipasi massa arah $\mathrm{X}$ dan arah $\mathrm{Y}$ dalam menghasilkan respons total telah melebihi $90 \%$.

Tabel 1. Data Perencanaan Model Struktur

\begin{tabular}{ll}
\hline & Data Gedung \\
\hline Jenis gedung & Perkantoran \\
Luas & $30 \times 56 \mathrm{~m}^{2}$ \\
Tinggi & 12 lantai $(42,5 \mathrm{~m})$ \\
Mutu baja $\left(f_{y}\right)$ & $400 \mathrm{MPa}$ \\
Mutu beton $\left(f_{c}\right)$ & $30 \mathrm{MPa}$ \\
Zona gempa & 6, tanah keras \\
Kolom lantai $1-12$ & $80 \times 80 \mathrm{~cm}^{2}$ \\
Shearwall & $35 \mathrm{~cm}$ \\
Komponen batas & $70 \times 70 \mathrm{~cm}^{2}$ \\
Balok & $50 \times 70 \mathrm{~cm}^{2}$ \\
Pelat & $15 \mathrm{~cm}$ \\
\hline
\end{tabular}

Hal ini menunjukkan bahwa meskipun penempatan dinding geser dari struktur tidak simetris namun struktur yang ditinjau ternyata memiliki ragam pertama dominan. Setelah didapatkan gaya-gaya dalam struktur berupa momen, gaya geser, dan gaya aksial kemudian dilakukan proses penulangan balok, kolom, dan dinding geser sesuai dengan SNI 03-2847-2002. ${ }^{9}$ 
Tabel 2. Modal Participation Mass Ratios

\begin{tabular}{cccccccc}
\hline Mode & Period & UX & UY & UZ & SumUX & SumUY & SumUZ \\
\hline 1 & 1.573911 & 75.3654 & 0.3777 & 0 & 75.3654 & 0.3777 & 0 \\
2 & 1.52696 & 0.4578 & 71.7617 & 0 & 75.8232 & 72.1394 & 0 \\
3 & 0.88919 & 0.0575 & 3.529 & 0 & 75.8807 & 75.6685 & 0 \\
4 & 0.463113 & 13.5747 & 0.3046 & 0 & 89.4554 & 75.9731 & 0 \\
5 & 0.449279 & 0.3583 & 12.9824 & 0 & 89.8137 & 88.9555 & 0 \\
6 & 0.252031 & 0.0084 & 0.9938 & 0 & 89.8221 & 89.9493 & 0 \\
7 & 0.23801 & 4.9613 & 0.0973 & 0 & 94.7834 & 90.0465 & 0 \\
8 & 0.230379 & 0.1191 & 4.5725 & 0 & 94.9025 & 94.6191 & 0 \\
9 & 0.155025 & 2.2629 & 0.0402 & 0 & 97.1654 & 94.6593 & 0 \\
10 & 0.149722 & 0.0439 & 2.1931 & 0 & 97.2093 & 96.8524 & 0 \\
11 & 0.126399 & 0.0012 & 0.2587 & 0 & 97.2105 & 97.1111 & 0 \\
12 & 0.114001 & 1.1748 & 0.0178 & 0 & $\mathbf{9 8 . 3 8 5 4}$ & $\mathbf{9 7 . 1 2 8 9}$ & 0 \\
\hline
\end{tabular}

Tabel 3. Modal Load Participation Ratios

\begin{tabular}{ccccc}
\hline Type & Accel & Stat \% & Dyn \% & Effective Period \\
\hline Accel & UX & 99.9949 & 98.3854 & 1.548 \\
Accel & UY & 99.9867 & 97.1289 & 1.483 \\
Accel & UZ & 0 & 0 & 0.000 \\
Accel & RX & 99.9999 & 99.9848 & 1.574 \\
Accel & RY & 100 & 99.9962 & 1.527 \\
Accel & RZ & 53.7176 & 95.074 & 0.000 \\
\hline
\end{tabular}

\section{ANALISA PUSHOVER}

Hasil analisa pushover berupa kurva kapasitas (capacity curve) ditampilkan dalam Gambar 8. Dari hasil analisa pushover seperti ditunjukkan pada Gambar 8 maka dapat diketahui besarnya waktu getar alami efektif yang terjadi pada struktur dengan cara mengubah kurva kapasitas dari non-linier menjadi kurva bi-linier. Kurva ini didapat dengan trial-error sehingga kira-kira seimbang antara luasan atas dan bawah. Kurva bi-linier untuk arah $\mathrm{X}$ dapat dilihat pada Gambar 9, sedangkan untuk kurva bi-linier arah Y dapat dilihat pada Gambar 10.

Dari Tabel 3 di dapatkan nilai Ti arah X adalah 1,548 detik:

$$
T_{e}=T_{i} \sqrt{\frac{K_{i}}{K_{e}}}=1,548 \cdot \sqrt{\frac{1,583}{1,417}}=1,636 \text { detik }
$$

Dimana:

$$
\begin{aligned}
\mathrm{Te}= & \text { waktu getar alami efektif yang } \\
\mathrm{Ti}= & \text { memperhitungkan kondisi in-elastis (detik). } \\
\mathrm{Ki}= & \text { Kektu getar fundamental elastis (detik). } \\
\mathrm{Ke}= & \text { Kekakuan lateral awal struktur }(\mathrm{KN} / \mathrm{m}) \\
&
\end{aligned}
$$

Dari Tabel 3 didapatkan Ti arah Y adalah 1,483 detik. Gambar 10 menunjukkan kekakuan lateral awal (Ki) berimpit dengan kekakuan lateral efektif $(\mathrm{Ke})$, jadi waktu getar alami tidak mengalami perubahan sampai tercapai kondisi leleh. Sehingga, waktu getar alami efektif (Te) sama dengan waktu getar fundamental elastis (Ti) yaitu 1,483 detik.

Akibat pembebanan gempa pada daerah gempa tinggi maka pada struktur akan terjadi sendi plastis. Sesuai dengan metode perencanaan kolom kuat-balok lemah, untuk desain pada struktur berdaktilitas penuh mekanisme tingkat tidak diperkenankan terjadi. Hasil analisa beban dorong berupa distribusi jumlah sendi plastis yang terjadi selengkapnya ditampilkan dalam Tabel 4 dan Tabel 5.

Kurva Kapasitas Pushover Arah X

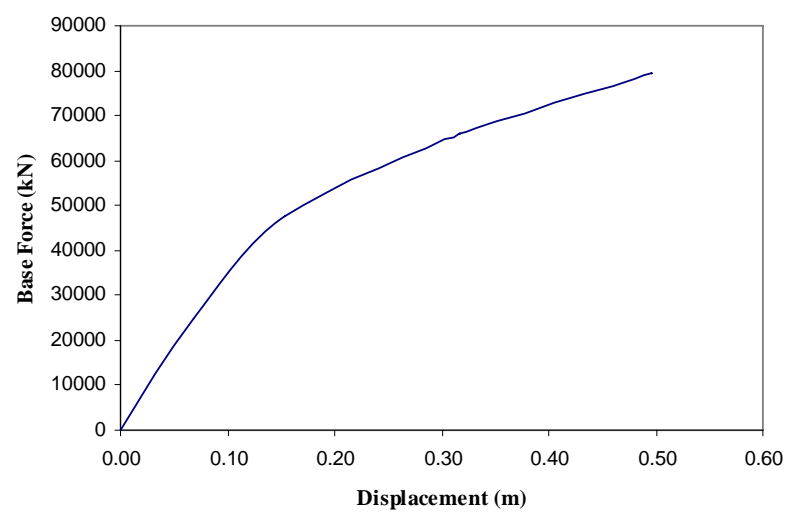

Gambar 8(a). Kurva kapasitas pushover arah X

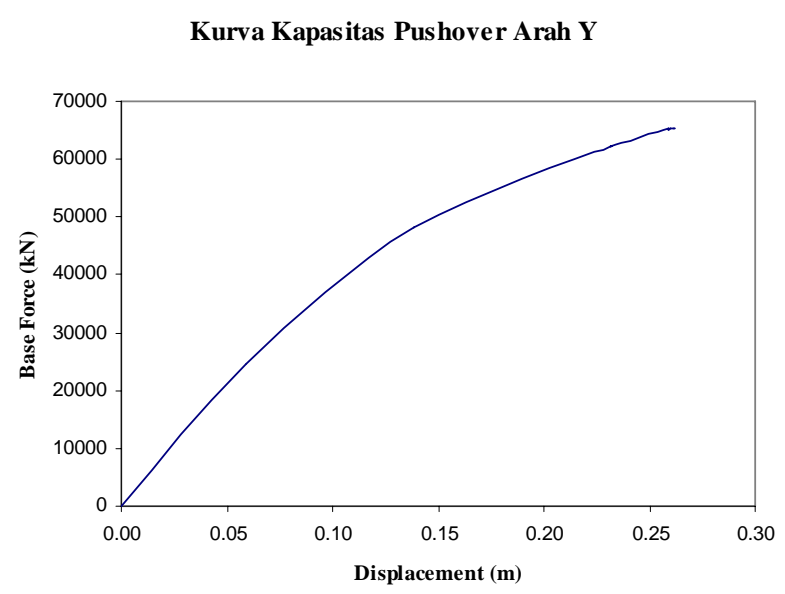

Gambar 8(b). Kurva kapasitas pushover arah Y 
Kurva Bi-Linier Pushover Arah X

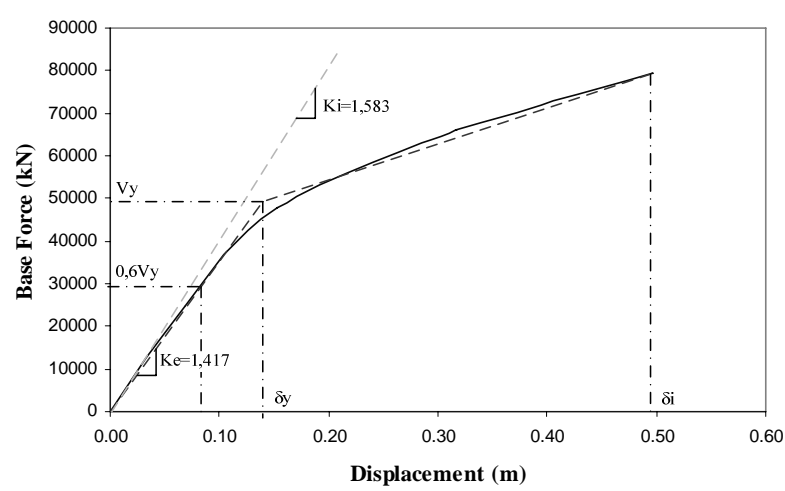

Gambar 9. Kurva kapasitas pushover Bi-linier arah X

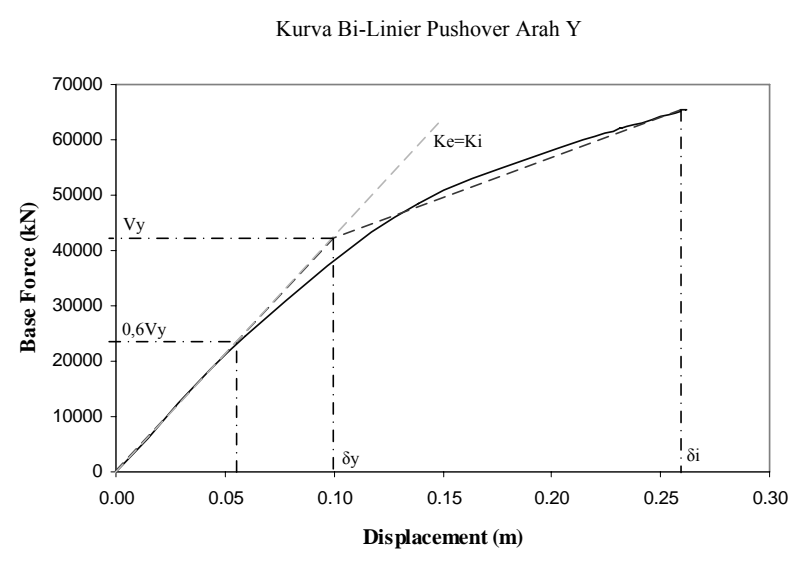

Gambar 10. Kurva kapasitas pushover Bi-linier arah Y

\section{TITIK KINERJA}

Terdapat empat metode dalam mencari besarnya titik kinerja struktur dari hasil analisa pushover.

\section{Metode Koefisien Perpindahan (FEMA 273/356)}

\section{Arah X :}

$\mathrm{Te}=1,636$ detik (lihat waktu getar alami efektif)

$\mathrm{C}_{0}=1,5$ (Tabel 3.2 FEMA 356 untuk bangunan lebih dari 10 lantai)

$\mathrm{C}_{1}=1$ untuk Te $\geq \mathrm{Ts}$

Ts $=0,5$ adalah waktu getar karakteristik dari kurva respon spektrum wilayah 6 tanah keras dimana terdapat transisi bagian akselerasi konstan ke bagian kecepatan konstan (lihat Gambar 12).

$\mathrm{C}_{2}=1,0(\mathrm{~T}>\mathrm{Ts}$, Framing type 2 , Life Safety)

$\mathrm{C}_{3}=1,0$ kekakuan pasca leleh adalah positif

$\mathrm{Sa}=0,42 / \mathrm{T}=0,42 / 1,636=0,257 \mathrm{~g}$ 's

Maka target perpindahan dapat dihitung sebagai berikut,

$$
\delta_{T}=C_{0} C_{1} C_{2} C_{3} S_{a}\left(\frac{T_{e}}{2 \pi}\right)^{2} g=0,256 \mathrm{~m}
$$

Arah Y :

$\mathrm{Te}=1,483$ detik (lihat waktu getar alami efektif)

$\mathrm{C}_{0}=1,5$ (Tabel 3.2 FEMA 356 untuk bangunan lebih dari 10 lantai)

$\mathrm{C}_{1}=1$ untuk Te $\geq \mathrm{Ts}$

Ts $=0,5$ adalah waktu getar karakteristik dari kurva respon spektrum wilayah 6 tanah keras dimana terdapat transisi bagian akselerasi konstan ke bagian kecepatan konstan (lihat Gambar 12).

$\mathrm{C}_{2}=1,0(\mathrm{~T}>\mathrm{Ts}$, Framing type 2, Life Safety)

$\mathrm{C}_{3}=1,0$ kekakuan pasca leleh adalah positif

$\mathrm{Sa}=0,42 / \mathrm{T}=0,42 / 1,483=0,283 \mathrm{~g}$ 's

Maka target perpindahan dapat dihitung sebagai berikut:

$$
\delta_{T}=C_{0} C_{1} C_{2} C_{3} S_{a}\left(\frac{T_{e}}{2 \pi}\right)^{2} g=0,232 \mathrm{~m}
$$

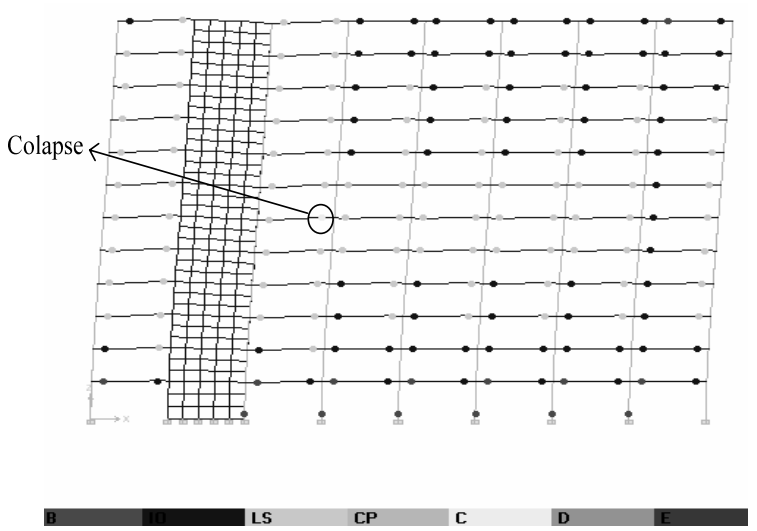

(a)

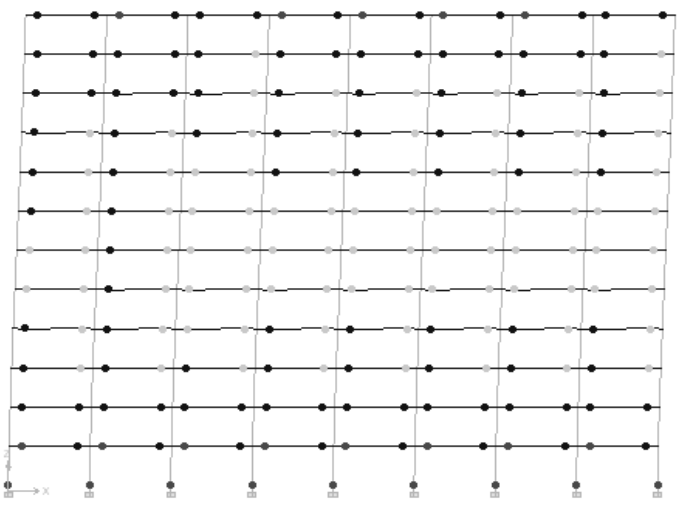

(b)

Gambar 11. pushover arah X step 5 (a) As 4, (b) As 2

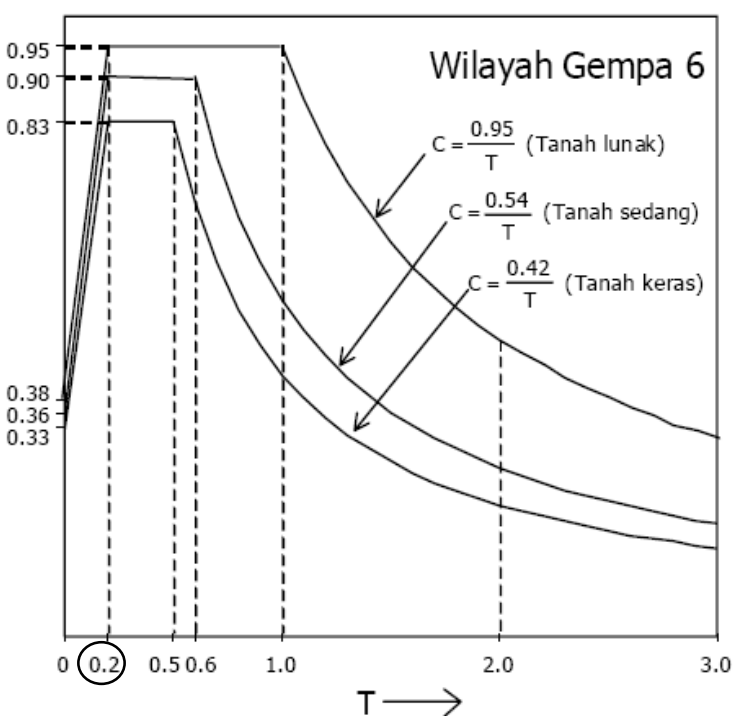

Gambar 12. Respon spektrum wilayah gempa 6 


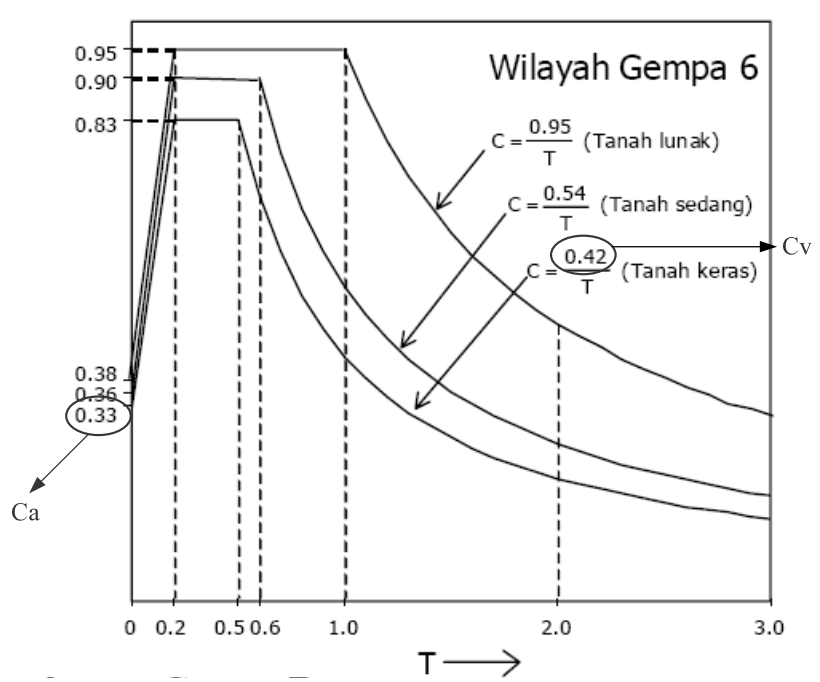

Gambar 13. Penentuan $\mathrm{Ca}$ dan $\mathrm{Cv}$ dari kurva respons spektrum (SNI 03 - 1726 - 2002)

\section{Metode Spektrum Kapasitas (ATC 40)}

Metode ini terdapat secara langsung pada ETABS V9.0.7, input yang diperlukan adalah sebagai berikut :

1. Dari kurva respon spektrum rencana SNI 03-1726-2006 untuk wilayah gempa 6 tanah keras diperoleh $\mathrm{Ca}=$ 0,33 dan $\mathrm{Cv}=0,42$ (Lihat Gambar 13)

2. Parameter damping $=5 \%$

3. Structural behavior: Type A (bangunan baru)

Dari Gambar 14 dapat dilihat bahwa titik kinerja arah $\mathrm{X}$ tercapai pada perpindahan 0,200 meter dan gaya geser sebesar 53020,862 kN. Sedangkan dari Gambar 15 dapat dilihat bahwa titik kinerja arah $\mathrm{Y}$ tercapai pada perpindahan 0,189 meter dan gaya geser sebesar $55935,063 \mathrm{kN}$.

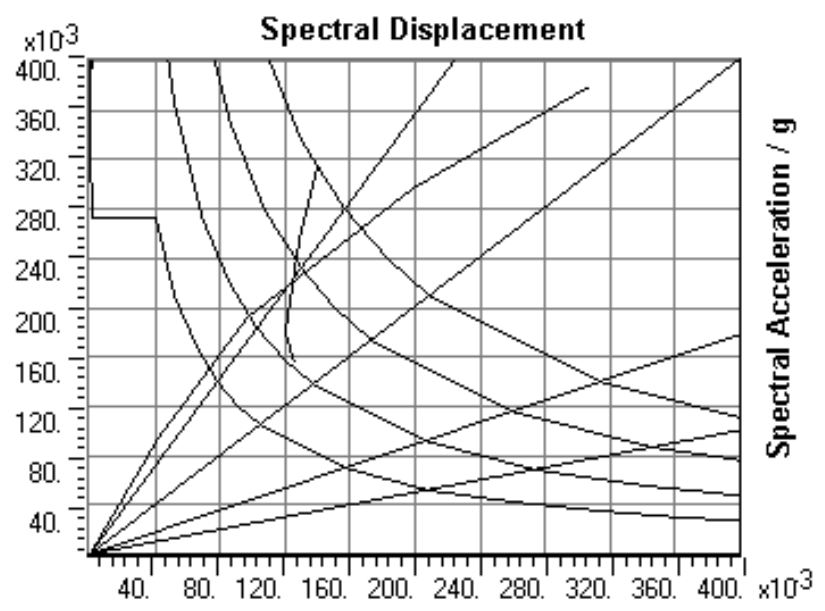

Cursor Location

Performance Point $(V, D)$

Performance Point $[\mathrm{Sa}, \mathrm{Sd}$ )

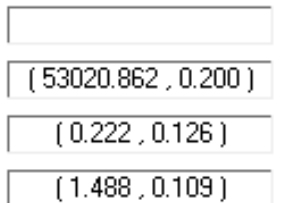

Performance Point (Teff,Beff)

Gambar 14. Capacity Spectrum arah X

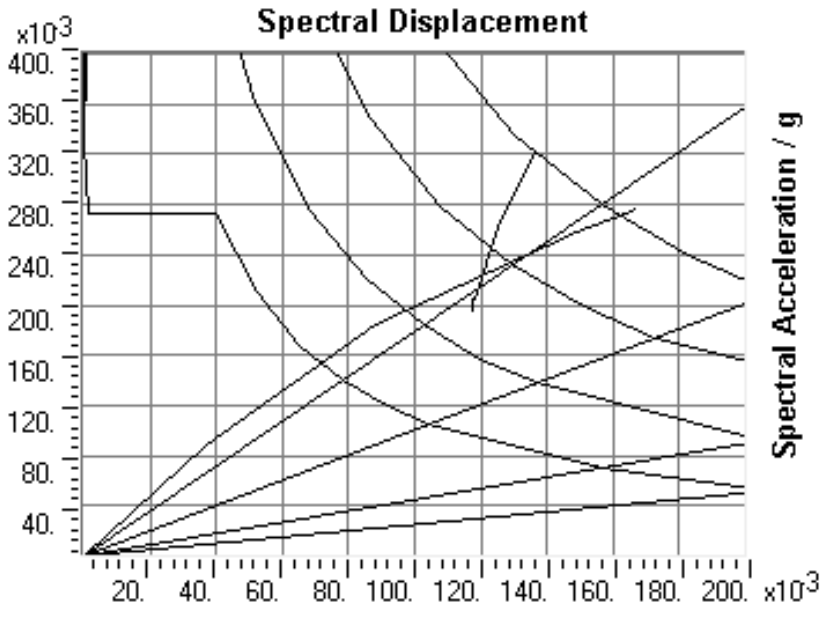

Cursor Location

Performance Point [V,D]

Performance Point $[\mathrm{Sa}, \mathrm{Sd})$

$\longdiv { [ 5 5 9 3 5 . 0 6 3 , 0 . 1 8 9 ] }$

Performance Point [T eff,Beff]

[0.224, 0.121]

Gambar 15. Capacity Spectrum arah Y

\section{Metode Koefisien Perpindahan yang Diperbaiki (FEMA 440) ${ }^{4}$}

Arah X:

$\mathrm{Te}=1,636$ detik (lihat waktu getar alami efektif)

Karena Te $>1$ detik maka $\mathrm{C}_{1}=1,0$

Karena Te $>0,7$ detik maka $\mathrm{C}_{2}=1,0$

$\mathrm{C}_{0}=1,5$ (Tabel 3.2 FEMA 356 untuk bangunan lebih dari 10 lantai)

$\mathrm{C}_{3}=1,0$ kekakuan pasca leleh adalah positif

$\mathrm{Sa}=0,42 / \mathrm{T}=0,42 / 1,636=0,257 \mathrm{~g}$ 's

Maka target perpindahan dapat dihitung sebagai berikut:

$$
\delta_{T}=C_{0} C_{1} C_{2} C_{3} S_{a}\left(\frac{T_{e}}{2 \pi}\right)^{2} g=0,256 m
$$

Arah Y:

$\mathrm{Te}=1,483$ detik (lihat waktu getar alami efektif)

Karena Te $>1$ detik maka $\mathrm{C}_{1}=1,0$

Karena Te $>0,7$ detik maka $\mathrm{C}_{2}=1,0$

$\mathrm{C}_{0}=1,5$ (Tabel 3.2 FEMA 356 untuk bangunan lebih dari 10 lantai)

$\mathrm{C}_{3}=1,0$ kekakuan pasca leleh adalah positif

$\mathrm{Sa}=0,42 / \mathrm{T}=0,42 / 1,483=0,283 \mathrm{~g}$ 's

Maka target perpindahan dapat dihitung sebagai berikut:

$$
\delta_{T}=C_{0} C_{1} C_{2} C_{3} S_{a}\left(\frac{T_{e}}{2 \pi}\right)^{2} g=0,232 m
$$

\section{Kinerja Batas Ultimit Menurut SNI 03-1726-2002 ${ }^{5}$}

Berdasarkan hasil analisa struktur didapatkan perpindahan atap maksimum arah $\mathrm{X}=0,0143 \mathrm{~m}$ dan arah $\mathrm{Y}=0,0191 \mathrm{~m}$

Simpangan ultimit yang terjadi :

Arah X : $\xi . X$

Arah $Y: \xi . Y$ 
Tabel 4. Distribusi sendi plastis pushover arah X

\begin{tabular}{|c|c|c|c|c|c|c|c|c|c|c|c|}
\hline Step & $\frac{\text { Displacement }}{(\mathrm{m})}$ & $\begin{array}{c}\text { Base Force } \\
(\mathrm{kN})\end{array}$ & A-B & B-IO & IO-LS & LS-CP & $\mathrm{CP}-\mathrm{C}$ & C-D & D-E & $>\mathrm{E}$ & TOTAL \\
\hline 0 & 0.000 & 0.000 & 3359 & 1 & 0 & 0 & 0 & 0 & 0 & 0 & 3360 \\
\hline 1 & 0.068 & 24743.346 & 2739 & 621 & 0 & 0 & 0 & 0 & 0 & 0 & 3360 \\
\hline 2 & 0.153 & 47681.254 & 2232 & 598 & 511 & 19 & 0 & 0 & 0 & 0 & 3360 \\
\hline 3 & 0.317 & 66110.586 & 2231 & 597 & 513 & 19 & 0 & 0 & 0 & 0 & 3360 \\
\hline 4 & 0.317 & 65994.266 & 2119 & 155 & 508 & 577 & 0 & 1 & 0 & 0 & 3360 \\
\hline 5 & 0.496 & 79231.938 & 2119 & 155 & 508 & 577 & 0 & 1 & 0 & 0 & 3360 \\
\hline 6 & 0.496 & 79213.469 & 3360 & 0 & 0 & 0 & 0 & 0 & 0 & 0 & 3360 \\
\hline
\end{tabular}

Tabel 5. Distribusi sendi plastis pushover arah Y

\begin{tabular}{|c|c|c|c|c|c|c|c|c|c|c|c|}
\hline Step & $\frac{\text { Displacement }}{(\mathrm{m})}$ & $\begin{array}{c}\text { Base Force } \\
(\mathrm{kN})\end{array}$ & - A-B & B-IO & IO-LS & LS-CP & $\mathrm{CP}-\mathrm{C}$ & C-D & D-E & $>\mathrm{E}$ & TOTAL \\
\hline 0 & 0.000 & 0.000 & 3359 & 1 & 0 & 0 & 0 & 0 & 0 & 0 & 3360 \\
\hline 1 & 0.059 & 24567.006 & 2859 & 490 & 11 & 0 & 0 & 0 & 0 & 0 & 3360 \\
\hline 2 & 0.139 & 48362.160 & 2429 & 736 & 175 & 20 & 0 & 0 & 0 & 0 & 3360 \\
\hline 3 & 0.232 & 62243.160 & 2429 & 735 & 176 & 20 & 0 & 0 & 0 & 0 & 3360 \\
\hline 4 & 0.232 & 62167.742 & 2339 & 721 & 270 & 30 & 0 & 0 & 0 & 0 & 3360 \\
\hline 5 & 0.259 & 65199.094 & 2339 & 721 & 270 & 30 & 0 & 0 & 0 & 0 & 3360 \\
\hline 6 & 0.259 & 65164.680 & 2337 & 722 & 271 & 30 & 0 & 0 & 0 & 0 & 3360 \\
\hline 7 & 0.260 & 65312.969 & 2337 & 722 & 271 & 30 & 0 & 0 & 0 & 0 & 3360 \\
\hline 8 & 0.260 & 65318.152 & 2332 & 726 & 272 & 30 & 0 & 0 & 0 & 0 & 3360 \\
\hline 9 & 0.261 & 65421.734 & 2332 & 726 & 272 & 30 & 0 & 0 & 0 & 0 & 3360 \\
\hline 10 & 0.261 & 65421.582 & 3360 & 0 & 0 & 0 & 0 & 0 & 0 & 0 & 3360 \\
\hline
\end{tabular}

Catatan :

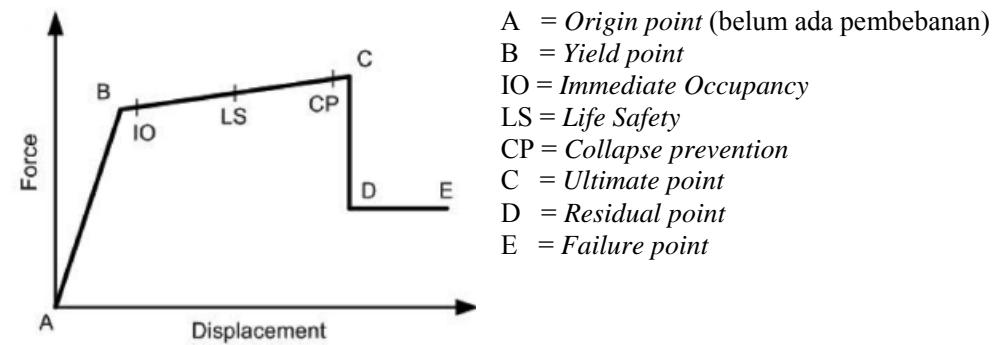

Dimana untuk gedung tidak beraturan nilai $\xi$ adalah

$$
\xi=\frac{0,7 \cdot R}{F S}=\frac{0,7 \cdot 8,5}{1}=5,95
$$

Jadi, simpangan ultimit arah $X=0,0143 \times 5,95=0,085 \mathrm{~m}$ simpangan ultimit arah $\mathrm{Y}=0,0191 \times 5,95=0,11 \mathrm{~m}$

\section{EVALUASI KINERJA}

Dalam mengevaluasi titik kinerja digunakan peraturan dari FEMA dan ATC - 40 sehingga di dapat perbandingan kinerja struktur menurut dua peraturan tersebut.

\section{Evaluasi Kinerja Menurut FEMA}

Rangkuman target perpindahan (performance point) dalam Tabel 6 menunjukkan dari keempat kriteria diatas diperoleh target perpindahan maksimum untuk arah $\mathrm{X}$ adalah 0,256 m (FEMA 356, FEMA 440) dan untuk arah $\mathrm{Y}$ yang paling maksimum adalah 0,232 (FEMA 356, FEMA 440). Ternyata dengan melihat Tabel 4 dan Tabel 5 dapat disimpulkan bahwa pada saat terjadi target perpindahan maksimum baik arah X dan arah Y, struktur masih berkinerja Life Safety. Hal ini menunjukkan bahwa gedung yang direncanakan sudah memenuhi kinerja yang diharapkan karena gedung berfungsi sebagai perkantoran.

Tabel 6. Rangkuman Target Perpindahan (Performance Point)

\begin{tabular}{lcc}
\hline \multirow{1}{*}{ Kriteria } & \multicolumn{2}{c}{ Target Perpindahan $(\mathrm{m})$} \\
\cline { 2 - 3 } & Arah X & Arah Y \\
\hline $\begin{array}{l}\text { Koefisien Perpindahan } \\
\begin{array}{l}\text { FEMA 356 } \\
\text { Spektrum Kapasitas ATC- }\end{array}\end{array}$ & 0.256 & 0.232 \\
$\begin{array}{l}\text { K0 } \\
\text { Koefisien Perpindahan }\end{array}$ & 0.200 & 0.189 \\
$\begin{array}{l}\text { FEMA 440 } \\
\text { Kinerja Batas Ultimit SNI } \\
1726\end{array}$ & 0.256 & 0.232 \\
\hline
\end{tabular}


Tabel 7. Deformation Limit berbagai Kinerja ATC-40

\begin{tabular}{lcccc}
\hline \multicolumn{5}{c}{ Performance Level } \\
\hline $\begin{array}{l}\text { Interstory } \\
\text { drift limit }\end{array}$ & $\begin{array}{c}\text { Immediate } \\
\text { Occupancy }\end{array}$ & $\begin{array}{c}\text { Damage } \\
\text { Control }\end{array}$ & $\begin{array}{c}\text { Life } \\
\text { Safety }\end{array}$ & $\begin{array}{c}\text { Structural } \\
\text { Stabiliity }\end{array}$ \\
$\begin{array}{l}\text { Maximum } \\
\text { total drift }\end{array}$ & 0.01 & $0.01-0.02$ & 0.02 & $0.33 \mathrm{Vi} / \mathrm{Pi}$ \\
$\begin{array}{l}\text { Maximum } \\
\text { inelastic } \\
\text { drift }\end{array}$ & 0.005 & $0.005-0.015$ & $\begin{array}{c}\text { No } \\
\text { Limit }\end{array}$ & No Limit \\
\hline
\end{tabular}

\section{Evaluasi Kinerja Menurut ATC - 40}

Evaluasi kinerja berdasarkan ATC-40 diberikan pada Tabel 7. Hasil evaluasi performance-based design sesuai ATC-40 adalah sebagai berikut :

$\underline{\operatorname{Arah} X:}$

$$
\begin{aligned}
& \mathrm{V}=53020,862 \mathrm{kN} \\
& \mathrm{D}=0,200 \mathrm{~m} \\
& \beta \text { eff }=0,109 \\
& \text { Tinggi total gedung adalah } 42,5 \mathrm{~m} \\
& \text { Drift rasio }=0,200 / 42,5=0,0047
\end{aligned}
$$

Arah Y :

$$
\begin{aligned}
& \mathrm{V}=55935,063 \mathrm{kN} \\
& \mathrm{D}=0,189 \mathrm{~m} \\
& \beta \mathrm{eff}=0,116
\end{aligned}
$$

Tinggi total gedung adalah $42,5 \mathrm{~m}$

Drift rasio $=0,189 / 42,5=0,00445$

Berdasarkan kriteria ATC-40 seperti yang terdapat pada Tabel 7 maka untuk drift rasio kurang dari 0,005 maka level kinerja struktur gedung yang direncanakan tergolong IO (Immediate Occupancy). Selain itu, nilai redaman efektif ( $\beta$ eff) yang diperoleh gedung lebih kecil dari batasan redaman efektif ( $\beta$ eff) maksimum yang diijinkan untuk gedung baru yaitu sebesar 40\%. Jadi, gedung yang direncanakan memenuhi syarat kinerja ATC-40.

\section{TIME HISTORY ANALYSIS}

Untuk mengkaji perilaku pasca-elastik struktur gedung terhadap pengaruh gempa rencana maka harus dilakukan analisa respon dinamik non-linier riwayat waktu, dimana percepatan muka tanah asli dari gempa masukan harus diskalakan sehingga nilai percepatan puncaknya menjadi sama dengan $\mathrm{A}_{0} \mathrm{I}$, dimana $\mathrm{A}_{0}$ adalah percepatan puncak muka tanah menurut Tabel 5 SNI 031726-2002 dan I adalah factor keutamaan menurut Tabel 1 SNI 03-1726-2002. ${ }^{5}$
Perhitungan skala intensitas sebagai berikut, untuk gempa El Centro 1994 percepatan puncak tanah asli = $0,3194 \mathrm{~g}$, sedangkan percepatan puncak tanah keras untuk wilayah gempa 6 SNI 03-1726-2002 =0,33g, faktor keutamaan gedung perkantoran $=1$, maka skala gempa $=$

$$
\frac{0,33}{0,3194} \cdot 1=1,0332
$$

Skala gempa secara lengkap untuk analisa dapat dilihat pada Tabel 8 .

\section{PERBANDINGAN HASIL TIME HISTORY DENGAN HASIL ANALISA PUSHOVER}

\section{Perpindahan (Displacement)}

Dengan analisa riwayat waktu dapat dilihat apakah struktur gedung yang ditinjau sudah melampaui target perpindahan atau belum. Hasil analisa untuk masingmasing gempa riwayat waktu dan analisa pushover terlihat dalam Gambar 16 dan Gambar 17. Hasil analisa riwayat waktu menunjukkan bahwa baik pada arah $\mathrm{X}$ maupun arah Y, perpindahan yang terjadi untuk gempa El Centro 1940, Santa Cruz 1989 , Sierra Madre 1991, Cape Mendocino 1992, dan Northridge 1994 belum melampaui target perpindahan dari FEMA 356 dan FEMA 440, namun Gempa El Centro sudah melampaui target perpindahan dari ATC-40 dan SNI 03-1726-2002. Perpindahan atap yang diakibatkan oleh beban gempa riwayat waktu masih lebih kecil dari hasil analisa pushover.

\section{Drift}

Pada studi kasus ini, batasan drift ratio ditentukan berdasarkan kinerja batas ultimit yang terdapat pada SNI 03-1726-2002 pasal 8.2. Syarat kinerja batas ultimit untuk gedung yang dianalisa adalah sebagai berikut:

Untuk lantai 1

Untuk lantai 2 - 12

$$
\Delta m=0,02 \times 4000=80 \mathrm{~mm}=0,08 \mathrm{~m}
$$

$$
\Delta m=0,02 \times 3500=70 \mathrm{~mm}=0,07 \mathrm{~m}
$$

Dari Gambar 18 dan Gambar 19 dapat diketahui bahwa secara keseluruhan baik hasil analisa oleh beban gempa riwayat waktu maupun oleh analisa pushover, drift antar tingkat yang terjadi masih lebih kecil atau belum melampaui kinerja batas ultimit SNI 03-1726-2002.

Tabel 8. Skala gempa untuk Analisa Riwayat Waktu

\begin{tabular}{lccc}
\hline & & \multicolumn{2}{c}{ Wilayah Gempa 6 SNI 03-1726-2002 } \\
\cline { 3 - 4 } Percepatan Gempa & Percepatan Puncak Tanah asli & Percepatan puncak tanah keras & Skala gempa \\
\hline El Centro 1940 & (g) & (g) & (g) \\
Santa Cruz 1989 & 0.3194 & 0.33 & 1.0332 \\
Sierra Madre 1991 & 0.3693 & 0.33 & 0.8937 \\
Cape Mendocino 1992 & 0.4479 & 0.33 & 0.7369 \\
Northridge 1994 & 0.5899 & 0.33 & 0.5594 \\
\hline
\end{tabular}




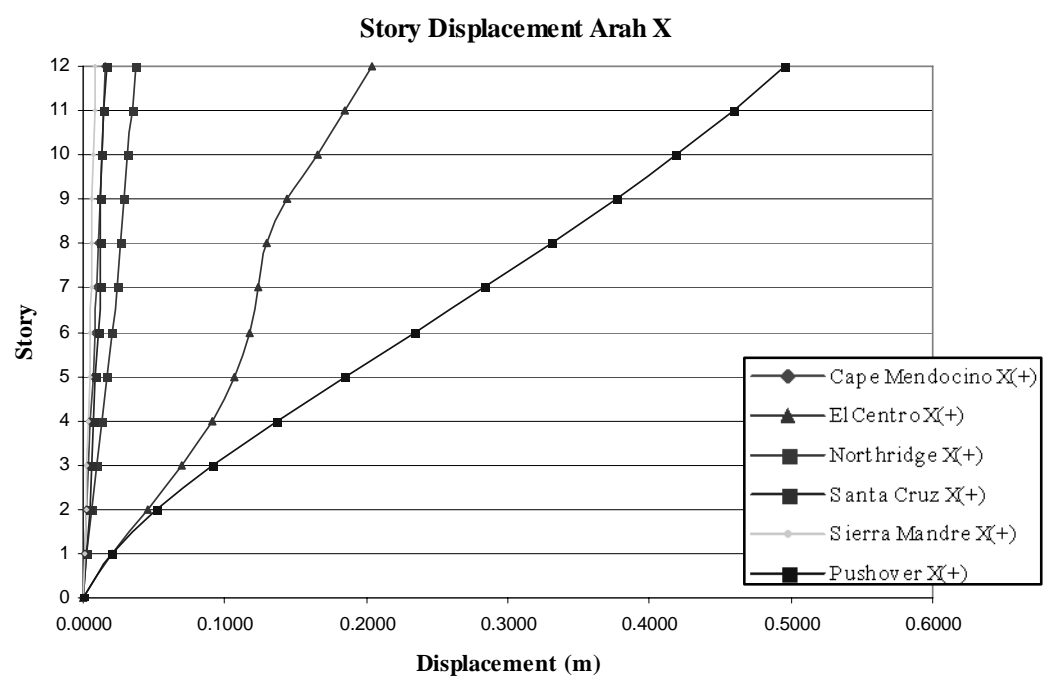

$\underline{\text { Gambar 16. Perbandingan Perpindahan tingkat Arah X Analisa Riwayat Waktu dan Analisa pushover }}$

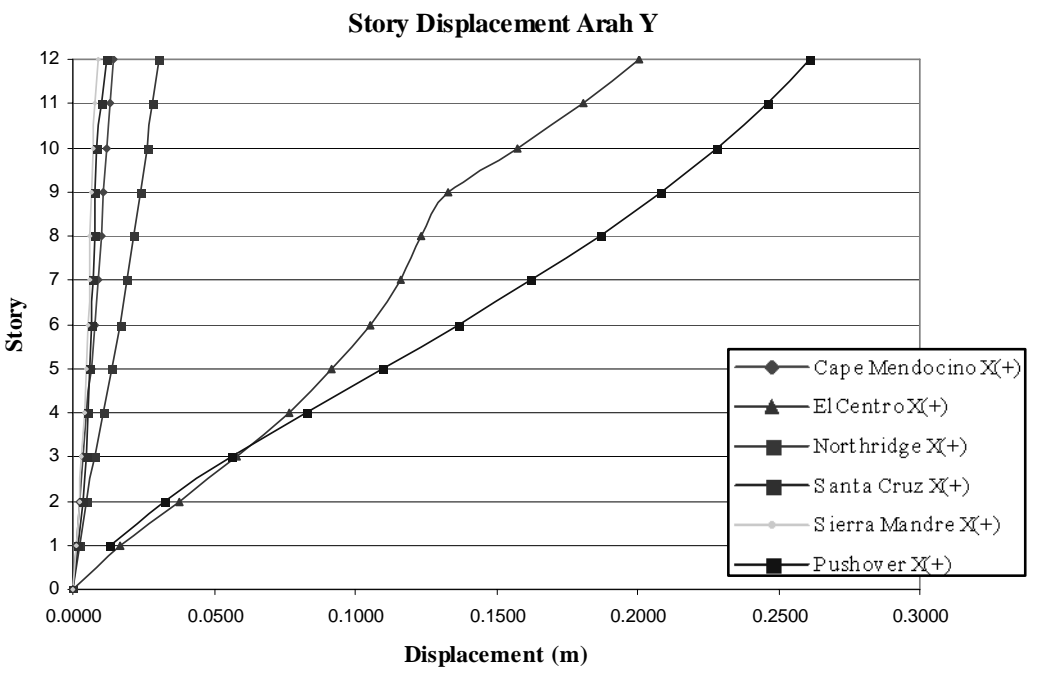

$\underline{\text { Gambar 17. Perbandingan Perpindahan tingkat Arah Y Analisa Riwayat Waktu dan Analisa Pushover }}$

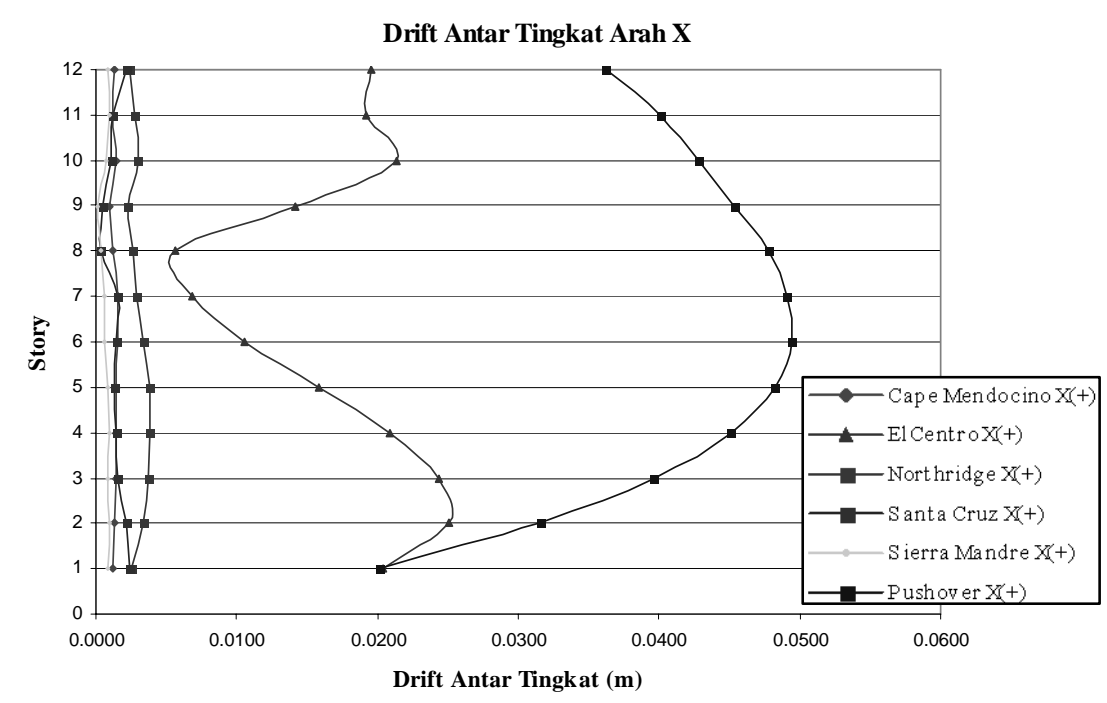

Gambar 18. Perbandingan Drift Antar tingkat Arah X Analisa Riwayat Waktu dan Analisa Pushover 


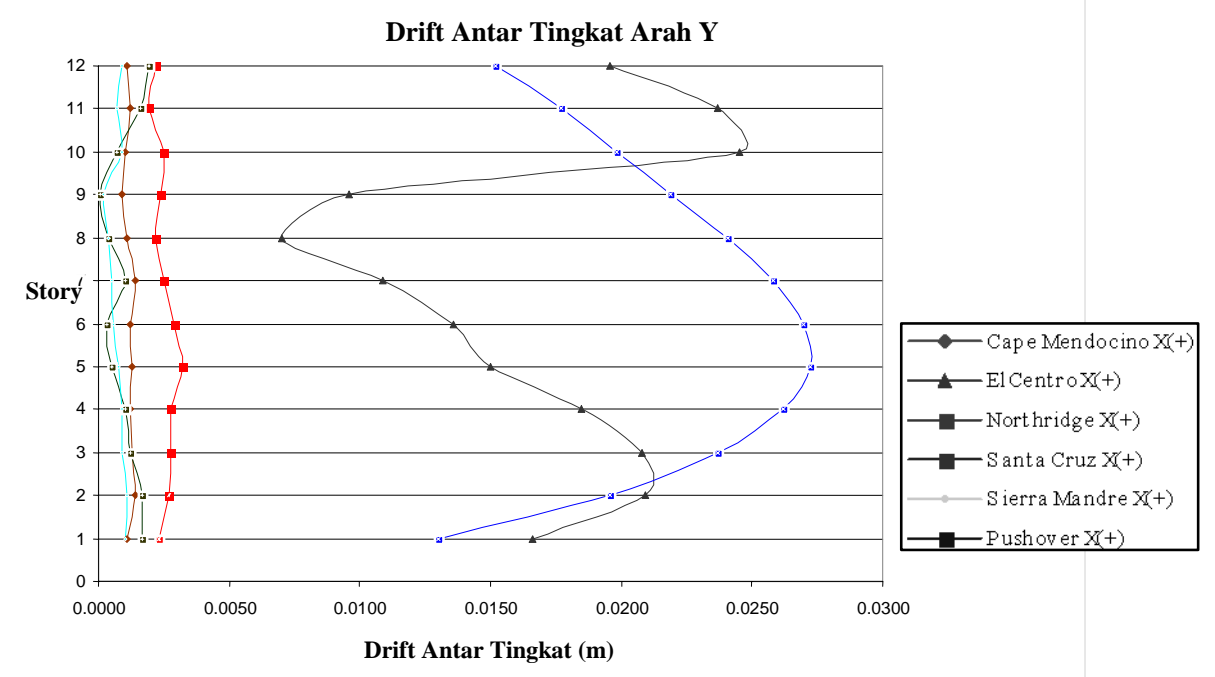

Gambar 19. Perbandingan Drift Antar tingkat Arah Y Analisa Riwayat Waktu dan Analisa Pushover

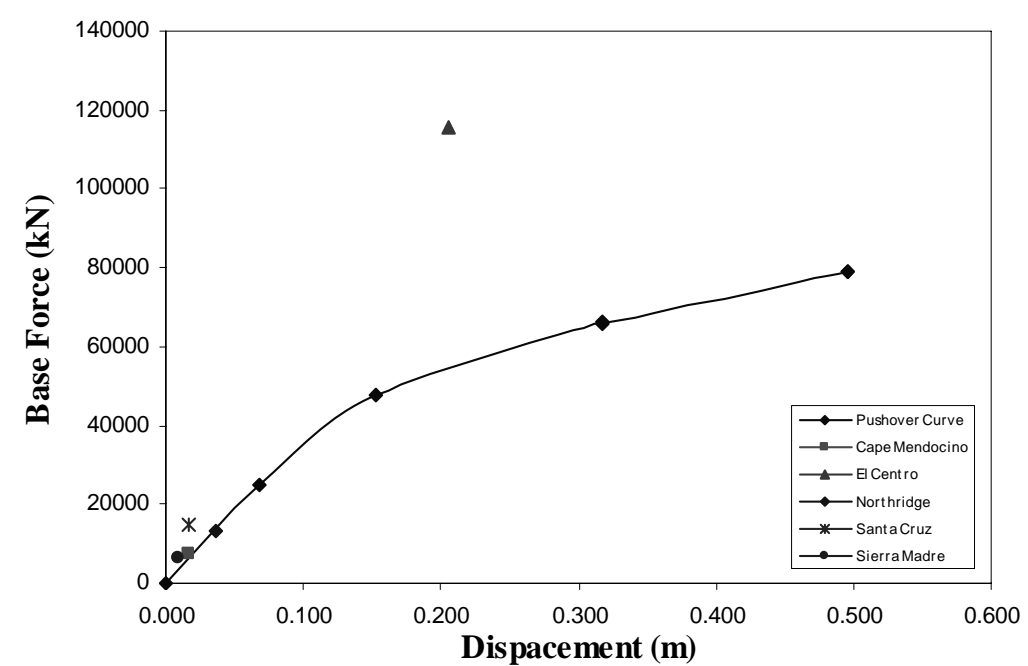

Gambar 20. Perbandingan Base shear dan Perpindahan Arah X Analisa Riwayat Waktu dan Analisa Pushover

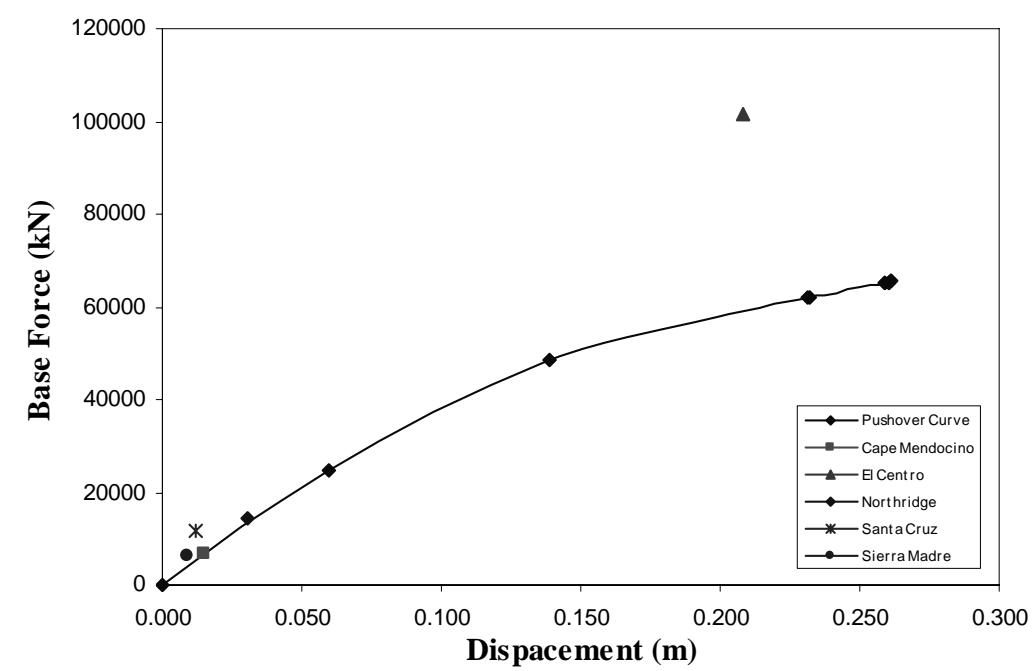

Gambar 21. Perbandingan Base shear dan Perpindahan Arah Y Analisa Riwayat Waktu dan Analisa Pushover 


\section{Base shear vs Perpindahan}

Perbandingan hasil dari analisa beban dorong dengan analisa riwayat waktu untuk nilai gaya geser dasar (base shear) vs maksimum envelope perpindahan dinyatakan dalam Gambar 20 dan Gambar 21. Disini dapat dilihat bahwa untuk gempa Santa Cruz 1989 , Sierra Madre 1991, Cape Mendocino 1992, Northridge 1994, dan El Centro 1940 nilai maksimum envelope perpindahan belum melampaui target perpindahan sesuai hasil dari analisa pushover.

\section{KESIMPULAN}

1) Sampai dengan target perpindahan (performance point) yang di dihitung berdasarkan FEMA 356, FEMA 440, dan SNI 03-1726-2002 struktur gedung yang didesain masih memiliki taraf kinerja Life Safety. Sedangkan evaluasi kinerja berdasarkan ATC-40 level kinerja struktur gedung yang direncanakan tergolong IO (Immediate Occupancy). Hal ini menunjukkan bahwa gedung yang didesain sudah memenuhi syarat kinerja sesuai FEMA 356, FEMA 440, dan ATC-40 karena gedung didesain sebagai gedung perkantoran.

2) Hasil analisa pushover menunjukkan bahwa distribusi sendi plastis hanya terjadi pada ujung-ujung balok dan kaki kolom. Hal ini sesuai dengan konsep "Kolom kuat - Balok lemah"

3) Studi kasus dengan beban gempa riwayat waktu El Centro 1940, Santa Cruz 1989, Sierra Madre 1991, Cape Mendocino 1992, Northridge 1994 apabila dibandingkan dengan analisa pushover, secara umum hasil perpindahan, drift, perbandingan base shear Vs perpindahan atap yang terjadi jauh lebih kecil, maka analisa pushover cukup rasional dan dapat diandalkan pada evaluasi perilaku seismik untuk perencanaan gedung.

4) Perpindahan atap yang dihasilkan oleh analisa dengan rekaman gempa El Centro 1940 adalah 0,206 m untuk arah $\mathrm{X}$ dan 0,208 untuk arah $\mathrm{Y}$ sedangkan titik kinerja maksimum sebesar $0,256 \mathrm{~m}$ untuk arah $\mathrm{X}$ dan $0,232 \mathrm{~m}$ untuk arah Y. Sehingga selisih analisa dinamik El Centro dan titik kinerja pushover sebesar $5 \mathrm{~cm}$ untuk arah X dan 2,4 cm untuk arah Y. Hal ini menunjukkan bahwa analisa pushover masih cukup akurat untuk gedung yang ditinjau karena gedung tersebut memiliki ragam pertama dominan. Apabila ragam pertama dari suatu struktur tidak dominan maka ragam yang lebih tinggi harus diperhitungkan. Dalam hal ini bisa memakai analisa modal pushover (Modal Pushover Analysis ).

\section{DAFTAR PUSTAKA}

1. Applied Technology Council. ATC 40 - Seismic Evaluation and Retrofit of Concrete Buildings. Redwood City, California, U.S.A.DC, 1996.

2. Federal Emergency Management Agency. NEHRP Commentary On The Guidelines For Seismic Rehabilitation Of Buildings. FEMA- 274 ,Washington DC, 1997.

3. Federal Emergency Management Agency. Pre standard And Commentary For The Seismic Rehabilitation Of Building. FEMA - 356, Washington, 2000.

4. ATC-55 Project. FEMA 440 - Improvement of Nonlinear Static Seismic Analysis Procedures. Federal Emergency Management Agency. Washington, D.C, 2004.

5. Badan Standardisasi Nasional. Tata Cara Perencanaan Ketahanan Gempa untuk Bangunan Gedung. SNI 03-17262002, 2002.

6. R. Darragh et al. First Interim Set of CSMIP Processed Strong-Motion Records From The Sierra Madre, California Earthquake of 28 Juni ,1991. California Department of Conservation, 1992.

7. R. Darragh et al. Processed CSMIP Strong-Motion Data From The Cape Mendocino/Petrolia Earthquake of April 25,1992. Release No.1. California Department of Conservation, 1992.

8. R. Darragh et al. Processed CSMIP Strong-Motion Records From The Northridge California Earthquake of January 17,1994. Release No.1. California Department of Conservation, 1994.

9. Purwono, R.; Tavio; Imran, I.; dan Raka, I G. P.2007. Tata Cara Perhitungan Struktur Beton Untuk Bangunan Gedung (SNI 03-2847-2002) Dilengkapi Penjelasan (S-2002). ITS Press.Surabaya, 2007. 